commented on then and now, showed us that others would listen if we, like she, had something important to say.

She is sorely missed already.

\author{
Paul VANDERWOOD \\ San Diego State University \\ San Diego, California
}

\title{
WARREN DEAN
}

Warren Dean died on May twenty-first, in Santiago, Chile. The senseless and infuriating cause of his sudden death-a defective gas line in a rented apartmentdeprived us of a remarkable colleague whose personal integrity and tireless intellectual curiosity greatly enriched the entire field of Latin American history. Warren is survived by his wife Elizabeth, his daughter and son, Julia and Thomas, and by his mother, Gabrielle Bach.

After graduating from the University of Miami in 1953, Warren tried out a variety of occupations, including (I learned to my genuine amazement) a job as a buyer at Bloomingdale's. His involvement in progressive politics and predilection for $\mathrm{Ca}$ ribbean culture eventually led to graduate work in Latin American history at the University of Florida-Gainesville. Warren's return to academia coincided with the early years of the Cuban Revolution, which he witnessed close-up during a brief stint at the University of Havana. This led to a master's thesis on Cuba during the Great Depression, but the increasing difficulty of travel to Cuba from the United States compelled Warren to consider another venue for his doctoral thesis. The intense pace of political and economic change in Brazil, and the widespread impression that a "pre-revolutionary" moment was developing there, moved Warren to focus on Brazilian history.

Warren was already an established and eminent figure in the field of Latin American studies when I entered graduate school in the early 1970s. Moreover, his reputation reflected not only his impressive scholarly accomplishments, but also his personal courage and commitments. At the time members of my cohort, many of us "graduates" of the antiwar movement, spoke in unusually respectful tones about Warren's experience as an assistant professor at the University of Texas. Legendwhich in this case turned out to be true-had it that Warren ejected an army captain, a "green beret" in transit from Southeast Asia to Colombia, from his course on Latin American history. This was an especially strong symbolic act at the height of the Vietnam War and during a period of repressive military rule in Brazil. The resulting furor apparently contributed to Warren's decision to leave Austin and join the history department at New York University in 1970. 
At NYU Warren played a central role in building the Center for Latin American and Caribbean Studies and creating a major graduate program in Latin American history. He became the William R. Kenan, Jr. Professor of History, and had recently served as chair of the department. During his tenure as chair, the NYU department added several young, innovative historians to its faculty, and it emerged as one of the finest in the country. In his role as a mentor for graduate students Warren was exceptionally generous with his time and ideas. Perhaps most important, he never sought to reproduce himself in his graduate students. To be sure, they benefited from the example of his outstanding and wide-ranging scholarship, but he encouraged them to follow their interests, and their intellectual passions, even if they diverged sharply from his own.

Warren is also a rare case of a "Brazilianist" whose work has been every bit as influential in Brazil as in the United States. Warren taught as a visiting professor or Fulbright lecturer at the University of São Paulo, the Federal University of Paraná, and several other leading Brazilian institutions. Moreover, every one of his books has been published in Portuguese, and has been widely cited and discussed in Brazil.

As a colleague, Warren provided an impressive example of how a scholar of considerable stature and distinction could remain unintimidating and unpretentious. In a profession where swollen and sensitive egos could be regarded as a routine occupational hazard, Warren appeared to have left his own ego in an airport locker a couple of decades ago. Warren hardly shrank from intellectual debate, but I never sensed the slightest rancor when he encountered criticism or disagreed with something a colleague had written. As a scholar whose work dealt with big, important issues in innovative and challenging ways, he seemed to expect, even welcome, a certain amount of contestation.

In this regard, Warren hit the ground running with his first book, The Industrialization of São Paulo, 1880-1945 (University of Texas Press, 1969). A study of São Paulo's transition from a coffee-plantation economy to Latin America's leadifg industrial center, it is no exaggeration to say that the book had an enormous impact on students of industrialization and development in both the United States and Brazil. Combining methods from economic and social history, The Industrialization of São Paulo boldly critiqued the then-dominant approach that placed fledgling industrialists and landed elites in opposing camps, with conflicting economic interests reinforced by the immigrant origins of factory-owners. Warren, deftly describing the "merger of emerging elites," argued that there were extensive overlaps between the two groups, and that many coffee-growing families had invested in the industrial sector, and even merged through marriage with the scions of wealthy immigrant clans.

Despite the book's emphasis on the crucial role of coffee planters and immigrant entrepreneurs in the industrialization process, it was by no means a celebration of the paulista elites, or the mystical bandeirante spirit. The study carefully scrutinized 
the limits of innovation and entrepreneurial activity in São Paulo, and skewered the supposedly progressive paulistas for their authoritarian response to the "social question." For labor historians, the book's discussion of worker surveillance, repression, and blacklisting, based on documents from the textile manufacturers' association, was a crucial revelation.

Soon after Warren's death, at a conference in Rio, the conference organizer sadly noted Warren's death in his opening speech, and briefly spoke of his contributions, especially his " "master work" Rio Claro: A Brazilian Plantation System, 1820-1920 (Stanford University Press, 1976).

The portrait of the coffee planters drawn in this book was even less sentimental or flattering than in Warren's study of industrialization. Whereas the existing historiography of Brazilian slavery tended to regard the paulista fazendeiro as a new breed of progressive planter open to new technology and unruffled by the prospect of slavery's abolition, Warren chronicled a planter class that, in its relations with its slaves, was every bit as rigid and brutal as those in other regions. Indeed, given the timing of the paulista coffee economy's growth, coinciding with the closing of the transatlantic slave trade, the paulista planters may have been even more ruthless in the exploitation of their enslaved workforce, and even more reluctant to manumit individual slaves. In its account of the emancipation process, Rio Claro shows the extent to which recalcitrant planters resorted to violence to keep their slaves on the fazenda. As for the planters' "accepting'" abolition, Warren persuasively argued that this only happened once massive escapes by the slaves made the process all but inevitable, and the mechanisms for substituting Italian immigrant workers in the coffee fields were in place.

By the late 1970s Warren had published two major books and a slew of influential articles. At that point in his career, he could have followed a well-worn path of publishing synthetic essays, or re-working previous research. Instead, he made a radical change in direction, developing a whole new field of interest in environmental history, and moving his research focus to a new region-the Amazon-that is considerably more daunting for the historian than the state of São Paulo. The result was Brazil and the Struggle for Rubber: A Study in Environmental History (Cambridge University Press, 1987). In this book Warren examined the history of the rubber boom and the subsequent failure of rubber cultivation in Brazil with primary emphasis on environmental factors.

On the face of it, this book has little in common with Warren's earlier monographs. Yet, on closer inspection, the reader can discern some shared qualities. One is Warren's continued skepticism, particularly toward the claims of those in positions of power. Throughout the book, Warren seems to take special delight in debunking hoary myths about the rubber trade long cherished by Amazonian elites, and has little patience for the various taxes and protections provided for Brazilian rubber, under the guise of nationalism, that only benefited a handful of wealthy investors. In contrast, the book openly admires the efforts of the scientific com- 
munity to combat the leaf blight that impedes rubber cultivation in Brazil. It even ends on an optimistic note, predicting that the continuous research into this problem may finally pay off. In this sense, Brazil and the Struggle for Rubber has no simplistic or fashionable "save the rainforest" message. The book respects the amazingly persistent power of environmental forces, but also applauds the efforts of those who seek to overcome them in economically productive and minimally destructive ways.

Beginning with his research on rubber, environmental history became Warren's abiding scholarly passion. Indeed, his recent work helped open up a whole new field of inquiry for historians of Latin America. Unlike an earlier historiography that often portrayed the environment as an unyielding and unchanging backdrop, Warren consistently emphasized the interaction between an inherently unstable environment and human endeavor. Fortunately for us, he was able to complete his pathbreaking study, With Broadax and Firebrand: The Destruction of the Brazilian Atlantic Coast Forest, which will be published later this year by the University of California Press. I eagerly look forward to reading it and thinking about its implications. I even expected to argue with him about it. But to my great sorrow, this time I will only be able to imagine what his gentle and reasonable responses would be.

BARBARA WEINSTEIN

SUNY at Stony Brook

Stony Brook, New York

\section{PUBLICATIONS}

\section{PANAMA}

Panama, the Canal and the United States: A Guide to Issues and References. By Thomas M. Leonard. [Regina Guides to Contemporary Issues, 9.] (Claremont: Regina Books, 1993. Pp. vii, 132. Maps. Chart. Bibliographic essay. No price.)

One of a series of "guides to contemporary issues" offered by the publisher to explore aspects of world politics, this work is composed of a narrative synthesis of the topic followed by a handy bibliographic essay. The intention of the publishers seems to be to reach the upper-level undergraduate audience and Leonard undoubtedly has succeeded. The story moves along briskly and rarely strays from the point, covering Panamanian history from 1513 to recent events under three headings: Panama's political history, the canal issue, and the events of 1989 and after. It is refreshing to see the Colombian angle brought to bear on the independence issue. Readers are also reminded of the long background of relations between Manuel Noriega and the United States government before the invasion of 1989 and subse- 